\title{
Barbara Hadryjańska
}

Poznań University of Life Sciences e-mail: hadryjanska@up.poznan.pl

ORCID: 0000-0003-2618-1092

\section{DIFFERENCES IN THE USE OF MUNICIPAL BONDS BY RURAL MUNICIPALITIES ACROSS THE POLISH TERRITORY}

\section{RÓŻNICE W UŻYCIU OBLIGACJI KOMUNALNYCH PRZEZ GMINY WIEJSKIE W POLSCE}

DOI: $10.15611 / \mathrm{pn} .2019 .10 .01$

JEL Classification: H720, H740

Summary: The main purpose of this paper was to present the extent of using municipal bonds and to find a statistically significant relationship between the location of a municipality in the macroregion and the use of bonds. The study was carried out in 2017. The basic research tool was a survey questionnaire administered in 606 rural municipalities., and132 surveys were sent back by rural municipalities located across all voivodeships. Approximately $90 \%$ of the municipalities surveyed access EU financing, loans and credits while less than $30 \%$ issue bonds. This seems to be primarily caused by the municipal authorities' cautiousness and reluctance to rely on instruments they do not know well. Municipalities located in the north-western and north-eastern macroregions willingly issued bonds.. Conversely, municipalities located in the eastern and central macroregions are the least interested in these instruments. A chi-squared-based analysis of correlation was performed.

Keywords: municipal bonds, rural municipalities, macroregion.

Streszczenie: Główne cele pracy to zaprezentowanie stopnia wykorzystania obligacji komunalnych, a także znalezienie związku statystycznie istotnego między położeniem gminy w makroregionie a wykorzystaniem emitowania obligacji. Badania przeprowadzono w $2017 \mathrm{r}$. Podstawowym narzędziem badawczym był kwestionariusz ankietowy rozesłany do 606 gmin wiejskich. Zwrotnie otrzymano od gmin wiejskich 132 ankiety. Około $90 \%$ gmin uczestniczących w badaniu korzystało z dofinansowania z UE, pożyczek i kredytów, a niecałe $30 \%$ - z emisji obligacji. Wydaje się, że ważnymi powodami takiego stanu rzeczy są ostrożność gmin oraz niechęć do korzystania z instrumentów, które nie są im dobrze znane. Gminy położone w makroregionie północno-zachodnim i w północno-wschodnim chętnie korzystały z emisji obligacji. Najmniejsze zainteresowanie nimi wykazały gminy z makroregionów wschodniego oraz centralnego. Analizę korelacji przeprowadzono, stosując statystykę chi-kwadrat.

Keywords: obligacje komunalne, gminy wiejskie, makroregion. 


\section{Introduction}

Decentralization processes are reflected in a number of ways, including the growing importance of local government which today's democratic states consider to be a system that makes public tasks management more efficient. Local government is a unit with its own financial budget used in particular to finance current tasks. Own revenues, targeted grants and subsidies can be allocated for that purpose. In turn, investments which promote development are mostly implemented with the use of extra-budgetary financing, including loans, credits, resources allocated in the European Union budget, or income from local government's securities. Particular focus needs to be placed on the latter group as it offers many advantages, especially compared to loans and credits.

The municipalities rely on their own revenues, targeted grants and subsidies when implementing multiple current tasks. These are the sources of funding for current expenditure necessary to carry out the local government's tasks. To meet all the needs of the local population, investment projects must be implemented which are decisive for the LGU's development level. These projects require additional funding which may be loans, credits, resources allocated in the European Union budget, or income from their own securities, including municipal bonds.

The purpose of this paper is to present the extent of using municipal bonds by Polish rural municipalities. These instruments offer considerable benefits which should be taken into account by the authorities. This paper attempts to present the differences in using that kind of financing in municipal-level development activities across the national territory. Hence the author relied on the division of the Polish territory into seven macroregions, as specified by the Central Statistical Office: the northern, north-eastern, south-western, central, Mazowieckie voivodeship, southern and eastern macroregions. The assumption behind this paper is the thesis that the use of municipal bonds depends on factors which include the macroregion where the municipality is located.

This paper presents the findings from empirical research (carried out in rural municipalities) on the use of municipal bonds as an repayable financing sources for investment activities.

\section{Municipal bonds as a source of financing for rural municipalities}

The key legal acts that regulate financial management at municipal level are the Constitution of the Republic of Poland, the Act on Incomes of Local Government Units, the Municipal Government Act, the Public Procurement Law Act, the Act on Liability for Infringement of the Fiscal Discipline, and the Act on Local Taxes and Fees [Ziółkowska 2012].

As provided for in Article 6, Para. 1 of the Municipal Government Act, "the scope of municipal activities includes all public matters of local importance which 
do not fall within the competence of other entities pursuant to separate Acts" [Ustawa z 8 marca 1990 r. o samorządzie gminnym...]. In Article 7.1 of the Act, the legislator defines own tasks of the municipality which are carried out to address the collective needs of a community. These include: matters related to environmental protection, road and economic infrastructure, healthcare and social assistance; support for families; residential construction; public education; culture; and promotion of the municipality. Own tasks are those which are local in nature and are financed by the municipality who acts on a relatively autonomous basis on its own behalf [Fleszer 2011].

In addition to own tasks, there is a separate category of delegated tasks allocated to municipalities under the applicable law. These are tasks related to state administration (e.g. preparing, organizing and conducting a municipal census; granting and disbursing targeted subsidies to cover expenses related to a natural or environmental disaster) and tasks related to organizing the preparation and conducting of general elections and referenda. The performance of delegated tasks is financed by the delegating body [Ofiarski 2010]. The limit of acceptability of tasks delegated to the municipality by state authorities lies between "addressing the collective needs of a community" and "public matters of local importance." Thus all other public matters fall within the competence of state administration bodies [Dolnicki 2009].

In addition to own and delegated tasks, there are also conferred tasks defined as tasks transferred to municipalities under agreements or arrangements between local government units or between a local government unit and the central administration. The scope and financing methods of the conferred tasks are provided for in the relevant agreements whose purpose is the delivery of municipal services relating to: water and sewage management, education, economic projects, social welfare, culture, tourism etc. [Zioło 2016].

Pursuant to the Act on Incomes of Local Government Units of November 2003 (Journal of Laws of 2003, No. 203, item 1966), incomes are divided into own revenues, general subsidies, targeted grants from the state budget, foreign funding, non-refundable funds and other funds.

Own revenues are collected from sources located within the operating area of the local government concerned, and are made available in the full amount to the local government for an indefinite period through the operation of law [Walczak, Kowalczyk 2010]. They primarily include: government levies, i.e. taxes, local fees, shares in taxes and fees, and income derived from local government property, income from the local government's economic activity and capital revenue. Government levies contribute around $38 \%$ (including $16.9 \%$ from the share in central taxes) to municipal income [Kornberger-Sokołowska, Zdanukiewicz, Cieślak 2012]. In 2014 the share of LGUs' own income in their total income mix was 50.7\% [Jastrzębska 2016].

However, own revenues have the largest share in the income mix of Polish municipalities (44.1\%), compared to $25.8 \%$ for subsidies and $30.1 \%$ for grants [Sprawozdanie z wykonania budżetów gmin za grudzień 2016...]. 
A general subsidy is the source of funding for local government tasks related to education, and enables financial support for economically weaker local government units. It is a general income and, in the case of municipalities, it consists of the education subsidy, the compensating subsidy and the balancing subsidy [Ziółkowska 2012].

Optional sources of municipal income include targeted grants from the state budget, allocated to such responsibilities as state administration tasks and other tasks provided for in relevant acts, tasks carried out by local government units under arrangements entered into with central administration authorities, and financing or co-financing own tasks [Dolnicki 2009].

An important source of municipal income - and the one under the greatest control by municipal authorities - may be the income derived from property and property rights. Control is mostly reflected by the ability to set the types and amounts of these incomes. Municipal property is separate from and not related to the Treasury or to the property of other local government units. Therefore the municipality may decide itself on how to use and allocate its property. Municipal income from the management of real estate owned by it can primarily include proceeds from real estate trading, i.e. proceeds derived from the sale, exchange, surrender, lease or letting of property (under the perpetual usufruct scheme or otherwise) or handing it over for perpetual management [Dolnicki 2009].

Foreign funds are a specific type of municipal budgetary income. In Poland these are mostly European Union funds delivered under operating programs financed by Structural Funds and the Cohesion Fund [Miszczuk 2009].

Sources of repayable financing for municipal operations are credits, loans, bond issuance and funds acquired from special international institutions. From the perspective of the rationale behind the decisions to use external funds, it is crucial to properly assess and analyze the mix of funding flows. As a consequence, the choice of external sources of financing should depend on factors which include the existing legal and budgetary restrictions; capital cost; flexibility of the debt instrument; risks involved in accessing capital; intended use of financing; availability of funding; time needed to acquire capital; capital repayment period and collateral; and the promotion effect [Śliwiński 2009; Dylewski et al. 2014].

Up till now bank credit and loans have been the most widely and commonly used methods of incurring debt for Polish local government units, accounting for approximately $90 \%$ of their total debt [Zobowiązania według papierów dłużnych... 2012]. However, recent years have seen growing interest from municipalities in an alternative source of long-term financing, namely the issuance of debt securities (municipal bonds). This is a specific type of loan which provides the local government units with a greater degree of freedom than bank credits. Indeed, the LGUs can seek funding from the many parties interested in this form of capital investment, thus avoiding intermediaries [Jędrzejewski 2007]. 
Municipal bonds can be defined as government securities issued by local government units in order to finance investment projects implemented as part of the tasks assigned to them under the relevant acts. Municipal bonds include revenue bonds issued to finance investment projects or other projects intended to generate income for debt repayment. Entities authorized to issue this type of bonds are municipalities, districts, voivodeships, their associations and the capital city of Warsaw [Kozuń-Cieślak 2008], however local government units rarely rely on it to access investment funds. In 2012 the ratio of liabilities incurred by LGUs on account of securities to total debt instruments, i.e. loans, credits and payable liabilities, was only $8.5 \%$ [Zobowiązania według papierów dłużnych... 2012].

When it comes to investment risks, the legal public status of local government units makes revenue bonds (just like municipal bonds in general) one of the lowest-risk securities. An important attribute of municipalities as bond issuers is the fact that a local government unit cannot be declared insolvent and, theoretically, cannot go bankrupt. An unquestionable advantage of such issuers is that they own high-value fixed assets which allow them to establish collaterals such as pledges or mortgages. However, a local government unit has limited income autonomy resulting from fiscal governance. Financial management procedures of local government units are public (Article 11 of the Public Finance Act)) which reduces the room for diverting funds and guarantees the transparency of decision-making mechanisms. The provisions of the Bond Act provide the bondholders with another guarantee of a secure investment. Accordingly, funds derived from the issuance of bonds cannot be allocated by the municipality to purposes other than those stipulated in the terms and conditions of issuance. The liabilities of a local government unit can be made even more secure thanks to: Polish and international bank guarantees; guarantees of the National Bank of Poland; giving of security by the Treasury or an international financial institution; and payment of sureties by another local government unit [Kozuń-Cieślak 2008].

\section{A regional approach to how municipal bonds are used: empirical findings}

The empirical study was carried out in 2017. The basic research tool was a survey questionnaire. It included ten questions and was administered to 606 rural municipalities from the Rural Municipalities Association (RMA). The questionnaire was e-mailed with the active participation from the RMA management.

In the empirical study, the respondents were asked the following questions in the survey questionnaire: what methods of external financing for municipal investments did they use; did they issue municipal bonds, and if so, how often; what were the reasons for using or not using this form of fund acquisition, and what were the uses of funds derived from bond issuance. 
As a result 132 surveys were returned by rural municipalities located across all voivodeships (the response rate was around $22 \%$ ). The greatest number of replies was from the Mazowieckie voivodeship (19) and the smallest from the Lubuskie, Opolskie and Podkarpackie voivodeships ( 2 surveys each). Questionnaires were also returned from the Wielkopolskie and Lódzkie voivodeships (17 replies each), the Dolnośląskie and Kujawsko-Pomorskie voivodeship (13 replies each), the Lubelskie voivodeship (9 replies), the Małopolskie voivodeship (8 replies), the Podlaskie and Śląskie voivodeships (7 replies each), the Świętokrzyskie voivodeship (6 replies), the Pomorskie voivodeship (4 replies), and the Warmińsko-Mazurskie and Zachodniopomorskie voivodeships ( 3 replies). The analysis of surveys took account of the division into seven macroregions (Central Statistical Office, NUTS 1):

- northern macroregion, comprising the Pomorskie, Warmińsko-Mazurskie and Kujawsko-Pomorskie voivodeships (20 survey questionnaires);

- north-western macroregion, comprising the Wielkopolskie, Lubuskie and Zachodniopomorskie voivodeships (22 survey questionnaires);

- south-western macroregion, comprising the Dolnośląskie and Opolskie voivodeships (15 survey questionnaires);

- central macroregion, comprising the Łódzkie and Świętokrzyskie voivodeships (23 survey questionnaires);

- Mazowieckie voivodeship macroregion (19 survey questionnaires);

- southern macroregion, comprising the Małopolskie and Śląskie voivodeships (15 survey questionnaires);

- eastern macroregion, comprising the Lubelskie, Podkarpackie and Podlaskie voivodeships (18 survey questionnaires).

The vast majority of Polish rural municipalities (over 90\%) use EU subsidies, credits and loans to finance local government investments, while 38 municipalities opted for municipal bonds, most of them located in the south-western macroregion (nine municipalities, i.e. $41 \%$ of units located in that macroregion) and in the north-western macroregion (nine municipalities, i.e. 41\%) (Figure 1). Municipal bonds attract the least interest in the central macroregion $(13 \%)$ and eastern macroregion $(17 \%)$.

Of the rural municipalities who issued bonds, $40 \%$ did so only once; $31 \% 2$-two to three times, and $29 \%$ did so more than three times. The largest number of municipalities (7) who declared to have issued municipal bonds more than three times were found in the north-western macroregion. Four municipalities of the south-western macroregion used that method two or three times.

For most rural municipalities, the motive behind using municipal bonds was the ability to implement investments and the low costs of bond issuance (nearly $70 \%$ ), as well as the opportunity to access funds without applying the Public Procurement Act (50\% of interviewees) (Figure 2). In macroregions which are highly active issuers of municipal bonds (i.e. the north-western and south-western macroregions), the most frequent reasons for doing so were low costs of bond issuance, investment 
opportunities and the opportunity to access funds without applying the Public Procurement Act. Macroregions which rarely used municipal bonds declared the main reasons for issuing them to be gaining new knowledge and experience, and the low value of interest coupons.

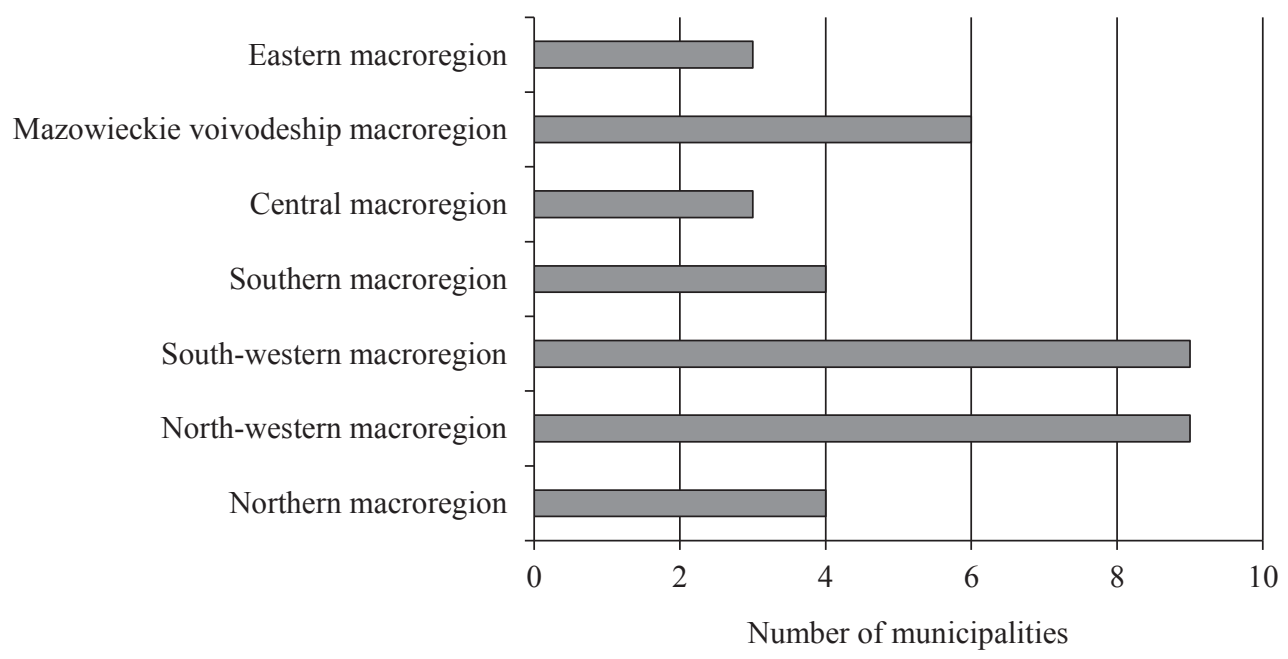

Fig. 1. Number of municipalities who use municipal bonds by region

Source: own study.

Opportunity to access funds without applying the Public Procurement Act

It allowed us to access Union funds

We gained new knowledge and experience in using this type of instruments

Ability to implement important investments

Non-financial benefits, e.g. marketing, image building

Low value of interest coupons

Low organizational costs of the issuance process

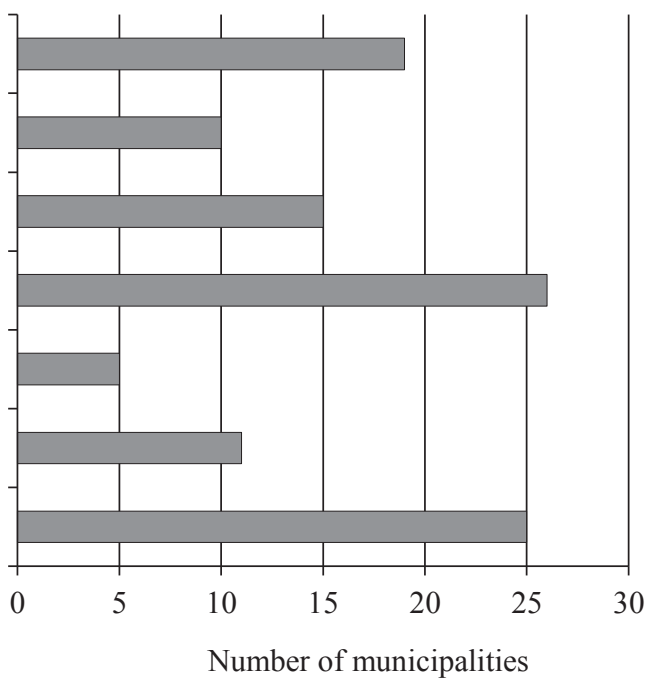

Fig. 2. Reasons behind using municipal bonds in rural municipalities

Source: own study. 
Rural municipalities in the north-western and south-western macroregions indicated that the funds derived from the issuance of bonds were mostly allocated to the following three areas: road infrastructure, environmental protection and education. Conversely, macroregions which issued municipal bonds to a smaller extent allocated the respective funds to education and to other areas such as sanitary facilities, repayment of earlier debt, purchase of real estate, and to compensate their budget deficit (Figure 3).

In macroregions which issued municipal bonds more frequently than other ones, municipalities not interested in bonds as a way of accessing investment funds stated the main reasons for their reluctance to be the concern over excessive indebtedness and the difficulties in finding purchasers of bonds. Municipalities located in the southern and northern macroregions indicated other reasons than those specified in the questionnaire, such as the absence of need to use such instruments, the use of credits as an easier way of accessing financial resources, or the excessive risk.

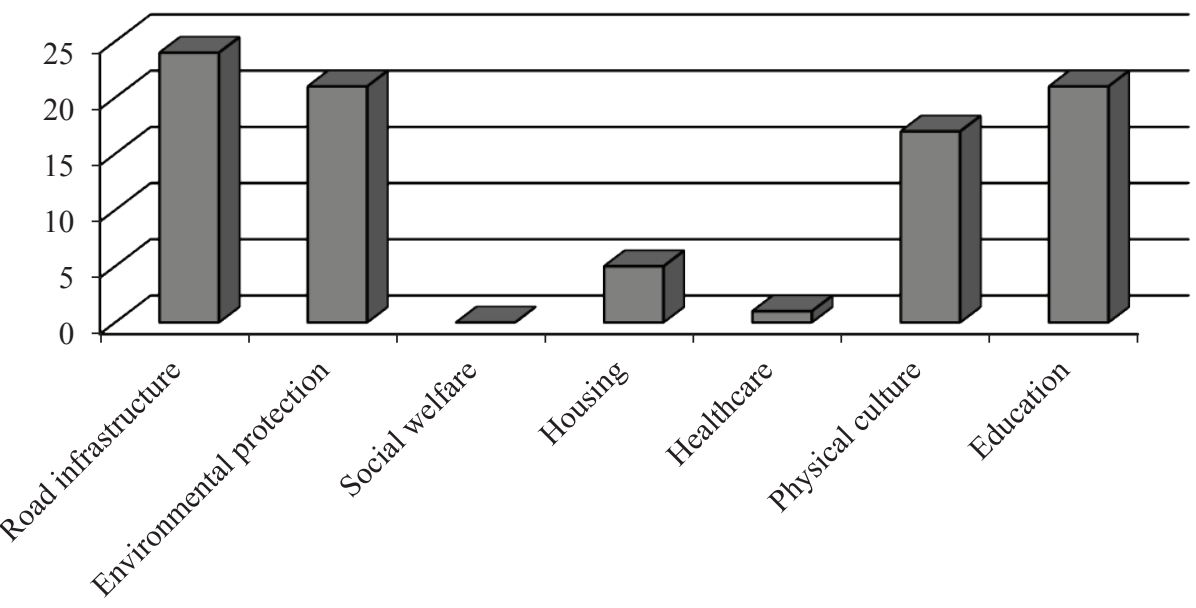

Number of municipalities

Fig. 3. Allocation of funds derived from the issuance of municipal bonds Source: own study.

Revenue bonds are a specific form of municipal bonds used only by two of the municipalities surveyed. Thus, it may be concluded that rural municipalities are not interested in revenue bonds as a source of financing for potential investments (as many as $98 \%$ of respondents did not use that source).

The author of this paper wanted to solve that research problem and answer the following question of whether there is a relationship between the location of a rural municipality and the amount of municipal incomes and expenses, on the one side, and the degree to which it relies on municipal bonds as an opportunity for accessing 
additional funds, on the other. The correlation coefficient was used to measure the strength of relationship between these aspects. The starting point for calculating the correlation coefficients for qualitative characteristics measured on a nominal scale was to build a bipartite table. Following this, total chi-squared was calculated and compared with the critical value of 12.59. If total chi-squared is above that level, the relationship can be found statistically significant and generalized into all rural municipalities. The strength of correlation was assessed by calculating Pearson's contingency coefficient $(\mathrm{C})$ which ranges from zero to one. The greater the $\mathrm{C}$, the stronger the relationship between the characteristics considered [Wysocki, Lira 2003; Gonick, Smith 2011].

Table 1 presents only those features covered by the study which in addition to being correlated are statistically significant. The strongest correlation was found between the municipality's location (macroregion) and the allocation of funds derived from the issuance of municipal bonds to diverse purposes. One possible interpretation is that the location of a municipality is related to the way it spends funds derived from the issuance of bonds. The relationship is particularly strong in the case of investments related to physical culture, environmental protection and road infrastructure. Particularly large amounts of funds derived from the issuance of

Table 1. Components of the chi-squared statistic indicative of a statistically significant relationship between the location of a rural municipality and the degree to which it uses bonds

\begin{tabular}{|l|l|c|c|}
\hline \multicolumn{1}{|c|}{ Question } & \multicolumn{1}{|c|}{ Available answers } & $\begin{array}{c}\text { Total } \\
\text { chi-squared }\end{array}$ & $\begin{array}{c}\text { Pearson's } \\
\text { contingency } \\
\text { coefficient }(C)\end{array}$ \\
\hline $\begin{array}{l}\text { Using external sources to finance } \\
\text { municipal investments }\end{array}$ & municipal bonds & 13.63 & 0.306 \\
\hline $\begin{array}{l}\text { Not using a specific source of external } \\
\text { financing }\end{array}$ & loan & 15.21 & 0.321 \\
\hline Frequency of issuing municipal bonds & not even once & 15.2 & 0.321 \\
\cline { 2 - 4 } & more than 3 times & 13.64 & 0.306 \\
\hline Reasons for issuing municipal bonds & ability to access EU funds & 15.31 & 0.322 \\
\hline $\begin{array}{l}\text { Allocation of funds derived from the } \\
\text { issuance of municipal bonds }\end{array}$ & road infrastructure & 14 & 0.31 \\
\cline { 2 - 4 } & environmental protection & 20.51 & 0.367 \\
\cline { 2 - 4 } & physical culture & 24.81 & 0.398 \\
\cline { 2 - 4 } & education & 13.83 & 0.308 \\
\hline Reasons for not issuing municipal bonds & complicated procedure & 13.69 & 0.307 \\
\cline { 2 - 4 } & lack of information & 13.43 & 0.304 \\
\hline Reasons for not issuing revenue bonds & lack of information & 13.43 & 0.304 \\
\cline { 2 - 4 } & complicated procedure & 12.62 & 0.295 \\
\hline
\end{tabular}

Source: own study. 
municipal bonds were allocated to these investment targets by municipalities located in the western part of the country. A statistically significant correlation was also found to exist in municipalities which indicated the opportunity to access EU support funds as a reason for issuing bonds. Another similar observation is the relationship between the municipality's location in a macroregion, on one side, and the lack of interest in loans as an instrument of external financing for municipal investments, and the fact that the municipality does not issue municipal bonds, on the other. A relationship was also revealed between the municipality's location and indicating the complicated bond issuance procedure and the lack of relevant information as the main reason for not using municipal and revenue bonds. Another statistically significant relationship is that between the municipality's location in a macroregion and the fact that it has issued bonds one or several times.

A statistically significant relationship was discovered between the level of municipal incomes as well as the fact that a municipality has not issued bonds (a contingency coefficient of $C=0.252$ ) and that it has issued bonds two or three times. However, no relationship was found to exist between the level of municipal expenditure and the degree to which a municipality relies on municipal bonds as a source of external financing for municipal investments.

\section{Final considerations}

From both the social and economic perspective, municipalities play an important role in the economy and in local communities. The municipality's main responsibility vis-à-vis the population is to perform its tasks in a way that best suits their needs. In order to do this, the municipalities carry out current tasks and investment tasks which usually require large amounts of financial expenditure. Some resources needed for investment development come from sources other than the municipality's own funds. Usually the municipalities must rely on extra-budgetary methods, including the option to issue municipal bonds. It turns out that approximately $90 \%$ of the municipalities surveyed access EU financing, loans and credits while less than $30 \%$ issue bonds which provide a multitude of benefits compared to the most popular forms of repayable financing.

Municipalities located in the north-western and north-eastern macroregions willingly issued bonds (compared to other regions), and many of them did so repeatedly. Conversely, municipalities located in the eastern and central macroregions are the least interested in these instruments.

A chi-squared-based analysis of correlation was performed finding a statistically significant relationship between the location of municipalities in a macroregion and some of the municipalities' replies to the survey. Based on the above, it may be concluded that a statistically significant relationship exists between the municipality's location and:

- the fact that the municipalities issue or do not issue bonds,

- not using loans as a source of external financing, 
- the frequency of issuing municipal bonds: it was the highest (over three times) in municipalities located in the north-western macroregion,

- indicating the ability to use EU funds as the basic reason for issuing bonds (especially in the south-western macroregion),

- allocating the funds derived from bonds to road infrastructure, environmental protection, physical culture and education (mostly in the north-western region),

- indicating the complicated procedure and the lack of information on the availability of such instruments as the reasons for not issuing bonds (mostly in the northern and eastern macroregions).

The above corroborates the thesis advanced at the beginning of this paper and allows for concluding that the use of municipal bonds depends on factors which include the macroregion where the municipality is located.

\section{Bibliography}

Dolnicki B., 2009, Samorzad terytorialny, Wolters Kluwer, Warszawa.

Dylewski M., Filipiak B., Gorzałczyńska-Koczkodaj M., Zioło M., 2014, Finanse publiczne. Aspekty teoretyczne i praktyczne, Wydawnictwo C.H. Beck, Warszawa.

Fleszer D., 2011, Samorzad terytorialny i jego zadania w świetle uregulowań prawnych - rozbieżności interpretacyjne, [in:] M. Stefański, H. Stępień (eds.), Gospodarka i finanse gmin w Polsce. Wybrane zagadnienia, Wyższa Szkoła Humanistyczno-Ekonomiczna we Włocławku, Włocławek.

Gonick L., Smith W., 2011, Statystyka. Przewodnik mocno ilustrowany, Wolter Kluwer Polska Sp. z o.o., Warszawa.

Jastrzębska M., 2016, Decentralizacja finansów publicznych w Polsce i finanse samorzqdowe w systemie finansów publicznych, [in:] J. Gliniecka, A. Drywa, E. Juchniewicz, T. Sowiński (eds.), Finansowanie jednostek samorzadu terytorialnego. Problemy praktyczne, CeDeWu, Warszawa. Oficyna Wydawnicza Branta, Bydgoszcz-Gdańsk.

Kornberger-Sokołowska E., Zdanukiewicz J., Cieślak R., 2012, Jednostki samorzqdu terytorialnego jako beneficjenci środków europejskich, Wolters Kluwer, Warszawa.

Kozuń-Cieślak G., 2008, Obligacje komunalne. Instrument dlużny dla jednostek samorzqdu terytorialnego, Wydawnictwo Naukowe PWN, Warszawa.

Miszczuk M., 2009, System podatków i opłat samorzqdowych w Polsce, Wydawnictwo C.H. Beck, Warszawa.

Ofiarski Z., 2010, Prawo finansowe, Wydawnictwo C.H. Beck, Warszawa.

Sprawozdanie z wykonania budżetów gmin za grudzień 2016, http:/www.mf.gov.pl/ministerstwo-finansow/dzialalnosc/finanse-publiczne/budzety-jednostek-samorzadu-terytorialnego/sprawozdania-budzetowe (17.09.2017).

Śliwiński P., 2009, Porównanie kredytu i emisji obligacji, [in:] P. Śliwiński, M. Stępniewski (eds.), Obligacje komunalne. Zagadnienie prawne, finansowe i praktyczne. Stan na 30 kwietnia 2009, Twigger, Warszawa.

Ustawa z 8 marca 1990 r. o samorządzie gminnym, Dz.U. nr 16, poz. 1591 (Obwieszczenie Marszałka Sejmu Rzeczypospolitej Polskiej z dnia 17 marca 2016 r. w sprawie ogłoszenia jednolitego tekstu o samorządzie gminnym, Dz.U. 2016, poz. 446).

Ustawa z dnia 13 listopada 2003 r. o dochodach jednostek samorządu terytorialnego, Dz.U. 2003 nr 203, poz. 1966 (Obwieszczenie Marszałka Sejmu Rzeczypospolitej Polskiej z dnia 18 marca 2015 r. w sprawie ogłoszenia jednolitego tekstu o samorządzie gminnym, Dz.U. 2015, poz. 513). 
Ustawa z dnia 27 sierpnia 2009 r. o finansach publicznych, Dz.U. 2009 nr 157, poz. 1240 (Obwieszczenie Marszałka Sejmu Rzeczypospolitej Polskiej z dnia 14 października 2016 r. w sprawie ogłoszenia jednolitego tekstu ustawy o finansach publicznych, Dz.U. 2016, poz. 1870).

Walczak M., Kowalczyk M., 2010, Rachunkowość i budżetowanie w zarzq̨dzaniu finansami gminy, Difin, Warszawa.

Wysocki F., Lira J., 2003, Statystyka opisowa, Wydawnictwo Akademii Rolniczej im. Augusta Cieszkowskiego w Poznaniu, Poznań.

Zioło M., 2016, Specyfika funkcjonowania jednostek samorzqdu terytorialnego a popyt na ustugi finansowe. Uwarunkowania - procesy - decyzje, [in:] B.Z. Filipiak, M. Zioło (eds.), Wspólpraca jednostek samorzadu terytorialnego z instytucjami finansowymi. Uwarunkowania - procesy - decyzje, Difin, Warszawa.

Ziółkowska W., 2012, Finanse publiczne. Teoria i zastosowanie, Wydawnictwo Wyższej Szkoły Bankowej, Poznań.

Zobowiązania według papierów dłużnych jednostek samorząa terytorialnego wg tytułów dłużnych w latach 2010-2 kwartały 2012, Ministerstwo Finansów, październik 2012, Warszawa. 